\title{
Colles' Fracture
}

National Cancer Institute

\section{Source}

National Cancer Institute. Colles' Fracture. NCI Thesaurus. Code C26724.

An extra-articular traumatic break in the distal radius with dorsal displacement of the distal fragment. 